\title{
Relationship Modeling of Critical Success Factors for Enhancing Sustainability and Performance in E-Learning
}

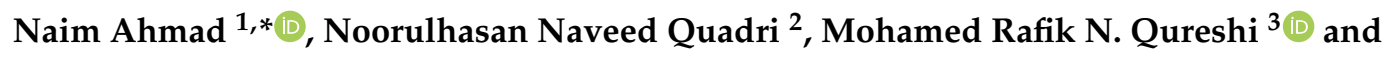 \\ Mohammad Mahtab Alam 4 (D) \\ 1 Department of Information Systems, King Khalid University, Abha 62529, Saudi Arabia \\ 2 Department of Computer Science, King Khalid University, Abha 62529, Saudi Arabia; qnaveed@kku.edu.sa \\ 3 Department of Industrial Engineering, King Khalid University, Abha 62529, Saudi Arabia; \\ mrnoor@kku.edu.sa \\ 4 Department of Medical Rehabilitation Sciences, King Khalid University, Abha 62529, Saudi Arabia; \\ mmalam@kku.edu.sa \\ * Correspondence: nagqadir@kku.edu.sa; Tel.: +966-17-241-8362
}

Received: 15 November 2018; Accepted: 12 December 2018; Published: 14 December 2018

check for updates

\begin{abstract}
E-learning, a technology-mediated learning approach, is a pervasively adopted teaching/learning mode for transferring knowledge. Some of the motivational factors for its wide adoption are time and location independence, user-friendliness, on-demand service, resource richness, and multi-media and technology driven factors. Achieving sustainability and performance in its delivery is of paramount importance. This research utilizes the critical success factors (CSFs) approach to identify the sustainable E-learning implementation model. Fifteen CSFs have been identified through the literature review, expert opinions, and in-depth interviews. These CSFs have been modeled for interdependence using interpretive structural modeling and Matriced' Impacts Croise's Multiplication Appliquée a UN Classement (MICMAC) analysis. Further, the model has been validated through in-depth interviews. The present research provides quantification of CSFs of E-learning in terms of their driving and dependence powers and their classification thorough MICMAC analysis. The E-learning system organizers may focus on improving upon the enablers such as organizational infrastructure readiness, efficient technology infrastructure, appropriate E-learning course design, course flexibility, understandable relevant content, stakeholders' training, security, access control and privileges, commitment, and being user-friendly and well-organized, in order to enhance the sustainability and performance in E-learning. This study will also help E-learning stakeholders in relocating and prioritizing resources.
\end{abstract}

Keywords: critical success factors (CSFs); enablers; E-learning system; interpretive structural modeling (ISM); knowledge transfer; Matriced' Impacts Croise's Multiplication Appliquée a UN Classement (MICMAC); teaching/learning; sustainable E-learning

\section{Introduction}

The present-day world is experiencing rapid changes in the field of education. These changes are due to revolutions in information and communication technology (ICT). With the emergence of computers, mobiles, and the Internet, sharing information has become very easy. Similarly, new computing paradigms such as cloud computing and data centers offer unlimited computing and storage facilities [1]. Besides, new Internet of Things-based solutions can connect various smart gadgets and people to establish a dynamic and interactive contextual environment [2]. With the 
increasing penetration of ICT, new technology-mediated learning methods such as E-learning have evolved. This offers lifelong continuous learning opportunities to remain efficient and updated [3,4].

E-learning provides richer resources than the traditional classroom in improving teaching/learning [5] and diminishes the barriers of time and space of conventional teaching. E-learning facilitates self-learning, minimizes supervision, and reduces the need for assessment of the traditional teaching mechanism [6]. Moreover, simultaneous immersion between work and study through E-learning develops a constant motivation for study and personal development [7]. Because of the widespread adoption of E-learning methodology and the modern trends in information technology, E-learning has become an effective methodology of teaching and learning at educational institutions [8]. Apart from the traditional approach of conventional lecture classes, E-learning may prove to be motivational in terms of multimedia usage. Moreover, it can be synergized with gamification technology in order to provide learning motivation, and initiatives such as ClassCraft may facilitate better learning through teamwork and fun [9].

The success of E-learning is due to its ability to share resources, flexibility, easy accessibility, and the inexpensive world-wide web (www). The United Nations Educational, Scientific, and Cultural Organization (UNESCO) considers E-learning as "learning through the internet and multimedia" [3]. In the present scenario of knowledge and information society, E-learning, using advanced ICT, has developed comprehensively to deliver learning and instruction [10]. As the latest teaching methods such as E-learning are very much in demand [11], educational institutions are becoming prudent in prioritizing the adoption of E-learning. Nevertheless, the implementation process requires comprehensive and effective planning, execution, and maintenance. Moreover, important factors such as infrastructure and environment, educators' competency, delivery of course contents, and change-agents must be considered and adapted appropriately to achieve successful E-learning implementation [12].

As the relationship between instructor and student is important to have effective knowledge transfer, a technology-mediated E-learning system may further reinforce this relationship. By implementing the well-developed strategic plan, the advantages of E-learning may be realized. E-learning is not merely a technology implementation, but rather the procedure of E-learning is multidimensional and interdisciplinary. Ordóñez [13] discussed and analyzed eight institutional factors that influence learners' experience, including support, uninterrupted instruction, social presence, learning policy, instructor and learner interaction, course design, and learning content. E-learning had been defined as follows: "E-learning is an approach to teaching and learning, representing all or part of the educational model applied, which is based on the use of electronic media and devices as tools for improving access to training, communication, and interaction, and which facilitates the adoption of new ways of understanding and developing learning" [14].

In addition to achieving high performance in E-learning, sustainability also needs to be ensured. Revolution in digital technology pressurizes E-learning technology management and subsequent quality standards. Insufficiency and inconsistency in funding cause E-learning failures. A sustainable E-learning program is required to fulfill the present and future needs of its stakeholders. Sustainable E-learning may be defined as follows: "E-Learning that has become normative in meeting the needs of the present and future" [15]. A sustainable E-learning program must be stakeholder-centered, cost-effective, and operationally efficient [16]. Good and effective sustainable E-learning management may lead to effective resource management and enhanced educational attainment. Sustainable E-learning management may also lead to effective professional development and innovation [17]. Sustainable E-learning-based open and distance learning provides an opportunity to offer the student-centered and learning-outcome driven system.

The theory of CSF is highly instrumental in any field to identify factors that are critical to success. Numerous studies exist in literature that attempt to identify important parameters in the context of the technology-enhanced learning (TEL), such as the work of [18]. Organizations need to carefully consider CSFs to have a successful implementation and manage CSFs that are essential for the implementation 
phase [19]. CSFs are the variables that are required to be measured in each phase of implementation, beginning from the planning phase, to ensure the process of execution [20]. Hence, it is essential to identify, control, and measure CSFs to ascertain the success of the entire system to achieve the quality standards of sustainable E-learning.

This study identifies important CSFs and develops the relationship model between CSFs for enhancing sustainability and performance in E-learning. There are structural relationships between variables that can be identified through contextual analysis by the experts in the field. The interpretive structural modeling (ISM) is a technique that guides the whole process and helps in the development of the hidden structure of interactions between variables. Further, it can help in distinguishing between enablers and outcome variables. Similarly, the Matriced' Impacts Croise's Multiplication Appliquée a UN Classement (MICMAC) analysis helps in clustering the variables into different domains of significance. CSFs' interaction in the form of enablers and outcome variables will help to enhance sustainability and performance in E-learning. Hence, the following objectives are set forth for this research.

- To identify the important CSFs in sustainable E-learning for successful implementation.

- To establish a model to show the hierarchy of CSFs in the form of enablers and outcome variables with the help of ISM and MICMAC techniques.

The remainder of the paper is organized into seven sections; namely, the research methodology, literature review, analysis, results and discussion, practitioner implications, limitations and future research, and conclusion.

\section{Research Methodology}

The first stage of the research identified all the CSFs present in the E-learning area, which resulted in 36 CSFs [21]. With the help of decision makers (DMs) in a brainstorming session, CSFs were reduced to 15 that played a significant role. These CSFs are explained in the following section of the literature review. The profiles of all the decision makers are mentioned in Table 1. All the DMs had more than five years of experience with the E-learning system. The CSFs number reduction helped to remove complexity in ISM, as the large number of CSFs would cause large matrices to be analyzed in addition to difficulty in pairwise comparisons.

Table 1. Profiles of decision makers and reviewers.

\begin{tabular}{cccc}
\hline Sr. No. & Participants' Role & Job Designation & Experience in Years (Total/E-Learning) \\
\hline 1 & Decision Maker & Senior Professor & $30 / 10$ \\
2 & Decision Maker & Assistant Professor & $13 / 10$ \\
3 & Decision Maker & Lecturer & $13 / 7$ \\
4 & Decision Maker & Lecturer & $12 / 10$ \\
5 & Reviewer & College Registrar & $12 / 10$ \\
6 & Reviewer & Dean of E-Learning & $5 / 5$ \\
7 & Reviewer & E-Learning Instructor & $10 / 10$ \\
8 & Reviewer & E-Learning Instructor & $8 / 8$ \\
9 & Reviewer & E-Learning Instructor & $8 / 8$ \\
10 & Reviewer & E-Learning Instructor & $7 / 7$ \\
\hline
\end{tabular}

In the second stage, the ISM technique was applied to the 15 CSFs identified in the first stage. Interactive learning processes were integrated into ISM, and various variables that are connected through some relationship were put together in a structural form [22]. It uses the basics of graph theory and employs interactive learning to exploit theoretical, conceptual, and computational leverage to illustrate a contextual relationship among variables. Thus, ISM identifies inter-relationships among variables to build a concrete model [23,24].

ISM is a kind of modeling that can quantify the effect of one variable on another. A group of DMs may judge the interactions between two variables. Many a time, the relationship is not simple, and thus needs to be simplified from a complex structure. The outcome of the ISM model is portrayed in terms of a diagraph that shows the inter-relationships. On the basis of the relationship, a series of 
matrix tables are formulated, known as a structural self-interaction matrix (SSIM). SSIM is formulated based on the comparison between two variables through a pair-wise comparison. Later, this SSIM is used to formulate the reachability matrix.

In summary, the ISM modeling methodology consisted of various stages, including identification of variables of interest, preparation of SSIM and reachability matrix, partitioning of the reachability matrix, incorporation of transitivity in SSIM, conical matrix construction, and diagraph development. Once the matrices were prepared, the driving power and dependence were calculated. The driving power and dependence were employed in the classification of variables using MICMAC analysis. Finally, the model was validated through in-depth interviews that lasted between $15 \mathrm{~min}$ and an hour with six reviewers with varying experience with E-learning, as mentioned in Table 1 . All the participants, decision makers, and reviewers contributed to the research with a high level of ethical standards and had no objection to including their opinions anonymously.

\section{CSFs of E-Learning through Literature Review}

Adoption of technology-assisted learning such as E-learning has increased in recent times as a result of the availability and affordability of information and communication technology. Nonetheless, E-learning implementation requires careful planning. This paper takes the critical success factors approach to implementing E-learning to make it effective and sustainable. The critical success factors are defined as "the limited number of areas in which results, if they are satisfactory, will ensure successful competitive performance for the organization" [25]. Numerous studies exist in the literature that have identified CSFs for E-learning implementation across the globe, including, for instance, studies in Iran [26,27], Serbia [28], United Arab Emirates (UAE) [29], Taiwan [30,31], Australia [32], Malaysia [33,34], Thailand [35,36], Sudan [37], Ghana [38], New Zealand [39], United Kingdom [40], and USA [41].

In order to identify CSFs in the area of E-learning, an extensive literature review was conducted in the previous study [21]. In summary, 64 research articles in total, published during 2005-2016, were chosen to extract CSFs, and were subsequently validated through a survey. This resulted in a total of 36 CSFs grouped into five dimensions including student, Instructor, design and contents, system and technological, and institutional management service. In this study, the inter-relationships between the CSFs were studied to evaluate, prioritize, and classify using ISM and MICMAC. During group decision making, using brainstorming methodology and employing the feedback of decision makers (DM), the 15 most significant CSFs were selected to keep the complexity of ISM manageable. The details of DMs are given in Table 1. In this session, CSFs were also ranked as per their mutual influence and dependence. The CSF variables, along with referring articles, from most independent to the final desired CSF appropriate system for enhancing sustainability and performance of the E-learning system, are shown in Table 2. In the subsequent paragraphs, these CSFs are explained.

Table 2. Critical success factors with references. ICT-information and communication technology.

\begin{tabular}{ccc}
\hline Sr. No. & Name of the Variable & References \\
\hline 1 & Network Security & {$[26,28,32,42]$} \\
2 & Efficient technology infrastructure & {$[12,26,27,29,30,32-35,37,38,43-46]$} \\
3 & Organizational Infrastructure readiness & {$[19,29,32,34,35,39,42,47,48]$} \\
4 & User-Friendly and Well-Organized & {$[28,30,40,42,49-51]$} \\
5 & Appropriate E-Learning Course Design & {$[27,29,35,40,51]$} \\
6 & Stakeholders Training & {$[19,32,35,47,52-54]$} \\
7 & Course Flexibility & {$[28,32,52]$} \\
8 & Understandable relevant Content & {$[26,28,40,42,52]$} \\
9 & Commitment & {$[26,40,42,55]$} \\
10 & Computer Competency (ICT Skills) & {$[31,35,36,40,43,48]$} \\
11 & Interaction with Instructor & {$[19,29,33,36,40,43,45]$} \\
12 & Interaction with other Students & {$[13,26,31,41,42,57]$} \\
13 & Motivation & {$[31,35,37,40]$} \\
14 & Easy language Communication & {$[35,48,49,58-61]$} \\
15 & Appropriate System for Enhancing Sustainability and performance & in E-Learning \\
\hline
\end{tabular}




\subsection{Network Security}

Network security is a paramount prerequisite for any information technology (IT) based initiative. Ever increasing threats to information security from both external and internal attackers have negatively influenced the utilization of the Internet for E-learning [32]. In the field of E-learning, some CSFs are technology related, such as reliability of hardware, bandwidth, accessibility, and network security [42].

\subsection{Efficient Technology Infrastructure}

A solid and efficient technology infrastructure foundation in course communication, delivery, and support is vital for the electronic course to be successful [35]. Efficient technology infrastructure along with good internet speed helps enable browsing of E-learning content in the campus. University authorities should properly implement access to the Internet throughout the university campuses, with sufficient internet speed [42,43]. Interactive E-learning with supporting technologies and vast learning resources is essential [32]. Students of the university are more interested in enrolling in electronic-based courses that offer a promising and positive approach to support an E-leaning based methodology [29]. A lack of good information technology (IT) infrastructure can lead to students dropping out of the online courses [30]

\subsection{Organizational Infrastructure Readiness}

The institutional readiness is related to issues of financial, infrastructure, cultural, and content readiness [47]. Eight factors that are supposed to be measured to assess E-learning implementation readiness are the following: "psychological readiness, sociological readiness, environmental readiness, human resource readiness, financial readiness, technological skill readiness, equipment readiness, and content readiness" [62]. Institutions must analyze their requirement and formulate a well-prepared road-map before implementation of E-learning [34]. Organizations need to have a systematic plan for financial support, proper feedback, and a plan for diversity evaluation [42].

\subsection{User-Friendly and Well-Organized}

This is a very important characteristic of the course content of E-learning methodology. The instructor organizes and arranges the course in an effective manner so that students feel comfortable using it [50]. Students highly appreciate content that is well-organized, efficiently accessible, properly written, interactive, of an appropriate length, valuable, and flexible [40].

\subsection{Appropriate E-Learning Course Design}

Appropriate E-learning course design makes online courses appealing and well-demanded. The visual formation and course blueprint design help students in learning the course [27]. The course display design interface has a significant impact on the successful implementation of E-learning systems. This component is of paramount importance and is used to bring the content of the course into a perfect frame that suits the students' understanding and skills [51].

\subsection{Stakeholders' Training}

The training of all the stakeholders such as university administrative staff, faculty, and students is essential. The customized knowledge and practice will help all stakeholders to increase the learners' ability in using and learning the course [52]. Appropriate training is a vital enabler for the implementation of E-learning as one cannot practice it without undergoing systematic training, as its operation depends on human skills. It delivers skills and knowledge that would drive the E-learning [54]. 


\subsection{Course Flexibility}

The E-learning course should be facilitated in on-demand mode. In the view of students, course flexibility involves the effectiveness and ease of taking the courses in their working, study, or free time [52]. System quality ensures the features and effectiveness of the executing platforms such as stability, flexibility, and reliability of courses [28].

\subsection{Understandable Relevant Content}

The extent of similarity between users' requirement vis-à-vis instructors' and institutes' offered features in the form of information, course content, and services should be essentially high [52]. E-learning may also be defined as the application of advanced computers and related technology to provide information, instruction, and content for learning [29]. One of the advantages of this technology is that it helps learners to get increased accessibility to information and better learning content [52].

\subsection{Commitment}

Commitment is a promise and obligation by the user to take the task seriously. Stakeholders delivering the right commitment in the teaching/learning process will help to achieve the required performance and sustainability [55]. Lecturers' and students' commitment is also very essential in the teaching/learning process, without which the system would not be in a position to deliver the required results [26]. It helps users to keep focus and leads to the success and learning of the course.

\subsection{Computer Competency (ICT Skills)}

E-learning is considered a bridge between modern and old skills [63]. E-learning implementation in the organizations faces some challenges if there are deficiencies of skills and absence of expertise to use a computer [64]. Some planning is required before the beginning of the course. The students using the E-learning methodology become familiar with basic computer abilities. Getting these abilities gears them to having an affirmative approach towards IT and fewer challenges with selecting contents [46]. In E-learning, attending some online coursework, technology literacy, and ICT skills enrich the students' learning experience [19].

\subsection{Interaction with Instructor}

The role of the virtualized teacher and student interaction is essential in the E-learning environment. Even though there is a bigger scope and various methods of interaction and communication between students and the instructor, there is the urgency of preparing a proper plan that should be employed for virtual learning environments in order to boost the learning process [48]. Proper interaction is even more important when the E-learning project requires support among students of different backgrounds, locations, and standards [31].

\subsection{Interaction with Other Students}

An E-learning system can deliver a significant effect if it is supported by a facility that enables communication and interaction between students [45]. The important requisites of learning approaches are the relations between learners themselves and teamwork in learning that provides good results because of peer interactions. Therefore, students' interactivity in the system is anticipated to be a unique issue that might affect students' adoption of E-learning [36].

\subsection{Motivation}

Motivation involves the power and aspiration of stakeholders to be continuously interested and committed to make an effort to attain a goal of using the E-learning system. Motivation is an important factor in online courses and is directly associated with the success of the students' and 
instructors' learning. Motivation is also observed as the most relevant factor related to the high level of accomplishment, especially as far as students' satisfaction, enjoyment, and confidence are concerned [13]. E-learning is a novel way of teaching and learning for many stakeholders in institutes of higher education. Installation of technology requires the involvement of the instructor and learners to use the services. Lin et al. (2011) found that the core team should motivate and encourage staff and students to use the E-learning courses.

\subsection{Easy Language Communication}

Communication is an exchange of information using some medium from sender to recipient. Simple language that is easily understood by the learners is required for the positive implementation of E-learning [37]. The language barrier could be a huge hindrance for Asian universities while adopting these E-learning platforms [31]. Hence, care must be taken to use simple language, and resources that make E-learning successful. FitzPatrick [35] concluded that the language barrier is a huge obstacle for the universities in Gulf countries.

\subsection{Appropriate System for Enhancing Sustainability and Performance in E-Learning}

Nowadays in higher educational institutes, technology-mediated learning has become a trend, such as virtual laboratory initiatives [58]. Many universities are adopting it in different modes to manage the needs of the new era. Several institutions of higher education are set up as only online learning providers and other traditional universities have started new online programs, while others have announced online learning components to improve some of their existing current programs [61]. The E-learning system can be made successful with the help of the realization of CSFs [49]. Enforcement of an appropriate system will contribute to augmenting sustainability and performance of E-learning in higher educational institutions $[59,60]$.

\section{ISM Analyses}

\subsection{Development of Structural Self-Interaction Matrix}

The 15 E-learning CSF variables earmarked at the end of the first brainstorming session were pairwise compared. The relationship between variables - for instance, $i$ and $j$-may be obtained by asking a simple question like 'leads to', 'increase each other', or 'no influence'; hence, an appropriate conclusion can be established. Thus, there could be four types of relationships between $i$ and $j$, indicated by letters $V, A, X$, and $O$, such as $i$ leads to accomplish $j, j$ is accomplished by $i, i$ and $j$ lead each other to increase both, and $i$ and $j$ do not have any relations. A total of 105 combinations of the distinct pairs were made from 15 variables and compared pairwise. This led to the development of the SSIM matrix shown in Table 3.

All 14 CSFs (1-14) led to the Appropriate System for Enhancing Sustainability and Performance in E-Learning (15), thus marked with "V". Similarly, CSF 13, Commitment, was accomplished or attained by the CSF 4, User-Friendly and Well-Organized, E-learning system, and hence was marked as " $\mathrm{A}$ ". As for "O", representing no relationship, CSF 1, Network Security, and CSF 13, Commitment, did not have any relationship. DMs did not identify any relationship to be termed as " $\mathrm{X}$ ", wherein CSFs cause mutual enhancement. In a similar manner, all the CSF variables of E-learning were judged and SSIM was prepared as shown in Table 3. 
Table 3. Matrix indicating structural self-interaction.

\begin{tabular}{|c|c|c|c|c|c|c|c|c|c|c|c|c|c|c|c|}
\hline S. No. & Elements & 15 & 14 & 13 & 12 & 11 & 10 & 9 & 8 & 7 & 6 & 5 & 4 & 3 & 2 \\
\hline 1 & Network Security & $\mathrm{V}$ & $\mathrm{V}$ & $\mathrm{O}$ & $\mathrm{O}$ & $\mathrm{O}$ & $\mathrm{O}$ & $\mathrm{O}$ & $\mathrm{V}$ & $\mathrm{O}$ & $\mathrm{V}$ & $\mathrm{O}$ & $\mathrm{V}$ & A & A \\
\hline 2 & Efficient Tech. Infrastructure & $\mathrm{V}$ & $\mathrm{V}$ & $\mathrm{O}$ & $\mathrm{O}$ & $\mathrm{V}$ & $\mathrm{V}$ & $\mathrm{V}$ & $\mathrm{V}$ & $\mathrm{O}$ & $\mathrm{V}$ & $\mathrm{V}$ & $\mathrm{V}$ & $\mathrm{A}$ & \\
\hline 3 & Organizational Infra. Readiness & $\mathrm{V}$ & $\mathrm{V}$ & $\mathrm{V}$ & $\mathrm{V}$ & $\mathrm{V}$ & $\mathrm{V}$ & $\mathrm{V}$ & $\mathrm{V}$ & $\mathrm{V}$ & $\mathrm{V}$ & $\mathrm{V}$ & $\mathrm{V}$ & & \\
\hline 4 & User-Friendly and Well-Organized & $\mathrm{V}$ & $\mathrm{V}$ & A & $\mathrm{V}$ & $\mathrm{O}$ & $\mathrm{O}$ & A & $\mathrm{V}$ & $\mathrm{O}$ & $\mathrm{V}$ & A & & & \\
\hline 5 & Appropriate E-Learning Course Design & $\mathrm{V}$ & $\mathrm{V}$ & $\mathrm{V}$ & $\mathrm{V}$ & $\mathrm{V}$ & $\mathrm{V}$ & $\mathrm{O}$ & $\mathrm{V}$ & $\mathrm{V}$ & $\mathrm{V}$ & & & & \\
\hline 6 & Computer Competency & $\mathrm{V}$ & $\mathrm{O}$ & A & $\mathrm{O}$ & $\mathrm{A}$ & $\mathrm{A}$ & $\mathrm{A}$ & $\mathrm{O}$ & $\mathrm{O}$ & & & & & \\
\hline 7 & Interaction with Instructor & $\mathrm{V}$ & $\mathrm{O}$ & $\mathrm{O}$ & A & A & $\mathrm{O}$ & $\mathrm{O}$ & $\mathrm{O}$ & & & & & & \\
\hline 8 & Interaction with other Students & $\mathrm{V}$ & $\mathrm{A}$ & $\mathrm{O}$ & $\mathrm{O}$ & $\mathrm{A}$ & $\mathrm{A}$ & A & & & & & & & \\
\hline 9 & Stakeholders Training & $\mathrm{V}$ & $\mathrm{V}$ & $\mathrm{O}$ & $\mathrm{O}$ & $\mathrm{O}$ & $\mathrm{O}$ & & & & & & & & \\
\hline 10 & Course Flexibility & $\mathrm{V}$ & $\mathrm{V}$ & $\mathrm{O}$ & $\mathrm{O}$ & $\mathrm{O}$ & & & & & & & & & \\
\hline 11 & Understandable relevant content & $\mathrm{V}$ & $\mathrm{V}$ & $\mathrm{V}$ & $\mathrm{V}$ & & & & & & & & & & \\
\hline 12 & Motivation & $\mathrm{V}$ & $\mathrm{O}$ & A & & & & & & & & & & & \\
\hline 13 & Commitment & $\mathrm{V}$ & $\mathrm{V}$ & & & & & & & & & & & & \\
\hline 14 & Easy Language Communication & $\mathrm{V}$ & & & & & & & & & & & & & \\
\hline 15 & $\begin{array}{l}\text { Appropriate System for Enhancing } \\
\text { Sustainability and Performance in E-Learning }\end{array}$ & & & & & & & & & & & & & & \\
\hline
\end{tabular}

\subsection{Development of Matrix for Reachability}

Once the SSIM was obtained, another matrix was derived from it, known as the reachability matrix. Various symbols, for instance, $\mathrm{V}, \mathrm{A}, \mathrm{X}$, and $\mathrm{O}$, were replaced with ' 0 ' or ' 1 ' by applying the following conversion rules on SSIM. After the substitution of all the $\mathrm{V}, \mathrm{A}, \mathrm{X}$ and $\mathrm{O}$, the initial reachability matrix was achieved, as shown in Table 4.

Substitute ' 1 ' in place $(i, j)$ of ' $V^{\prime}$ and ' ${ }^{\prime}$ ' on its transposed $(j, i)$ position

Substitute ' 0 ' in place $(i, j)$ of ' $A$ ' and ' 1 ' on its transposed $(j, i)$ position

Substitute ' 1 ' in place $(i, j)$ of ' $X$ ' and ' 1 ' on its transposed $(j, i)$ position

Substitute ' 0 ' in place $(i, j)$ of ' $O{ }^{\prime}$ ' and ' 0 ' on its transposed $(j, i)$ position

Table 4. Initial matrix to indicate reachability.

\begin{tabular}{ccccccccccccccccc}
\hline S. No. & Elements & $\mathbf{1}$ & $\mathbf{2}$ & $\mathbf{3}$ & $\mathbf{4}$ & $\mathbf{5}$ & $\mathbf{6}$ & $\mathbf{7}$ & $\mathbf{8}$ & $\mathbf{9}$ & $\mathbf{1 0}$ & $\mathbf{1 1}$ & $\mathbf{1 2}$ & $\mathbf{1 3}$ & $\mathbf{1 4}$ & $\mathbf{1 5}$ \\
\hline 1. & Network Security & 1 & 0 & 0 & 1 & 0 & 1 & 0 & 1 & 0 & 0 & 0 & 0 & 0 & 1 & 1 \\
\hline 2. & Efficient Tech. Infrastructure & 1 & 1 & 0 & 1 & 1 & 1 & 0 & 1 & 1 & 1 & 1 & 0 & 0 & 1 & 1 \\
\hline 3. & Organizational Infra. Readiness & 1 & 1 & 1 & 1 & 1 & 1 & 1 & 1 & 1 & 1 & 1 & 1 & 1 & 1 & 1 \\
\hline 4. & User-Friendly and Well-Organized & 0 & 0 & 0 & 1 & 0 & 1 & 0 & 1 & 0 & 0 & 0 & 1 & 0 & 1 & 1 \\
\hline 5. & Appropriate E-Learning Course Design & 0 & 0 & 0 & 1 & 1 & 1 & 1 & 1 & 0 & 1 & 1 & 1 & 1 & 1 & 1 \\
\hline 6. & Computer Competency & 0 & 0 & 0 & 0 & 0 & 1 & 0 & 0 & 0 & 0 & 0 & 0 & 0 & 0 & 1 \\
\hline 7. & Interaction with Instructor & 0 & 0 & 0 & 0 & 0 & 0 & 1 & 0 & 0 & 0 & 0 & 0 & 0 & 0 & 1 \\
\hline 8. & Interaction with other Students & 0 & 0 & 0 & 0 & 0 & 0 & 0 & 1 & 0 & 0 & 0 & 0 & 0 & 0 & 1 \\
\hline 9. & Stakeholders Training & 0 & 0 & 0 & 1 & 0 & 1 & 0 & 1 & 1 & 0 & 0 & 0 & 0 & 1 & 1 \\
\hline 10. & Course Flexibility & 0 & 0 & 0 & 0 & 0 & 1 & 0 & 1 & 0 & 1 & 0 & 0 & 0 & 1 & 1 \\
\hline 11. & Understandable relevant content & 0 & 0 & 0 & 0 & 0 & 1 & 1 & 1 & 0 & 0 & 1 & 1 & 1 & 1 & 1 \\
\hline 12. & Motivation & 0 & 0 & 0 & 0 & 0 & 0 & 1 & 0 & 0 & 0 & 0 & 1 & 0 & 0 & 1 \\
\hline 13 & Commitment & 0 & 0 & 0 & 1 & 0 & 1 & 0 & 0 & 0 & 0 & 0 & 1 & 1 & 1 & 1 \\
\hline 14. & Easy Language Communication & 0 & 0 & 0 & 0 & 0 & 0 & 0 & 1 & 0 & 0 & 0 & 0 & 0 & 1 & 1 \\
\hline 15. & Appropriate System for Enhancing & 0 & 0 & 0 & 0 & 0 & 0 & 0 & 0 & 0 & 0 & 0 & 0 & 0 & 0 & 1 \\
\hline & Sustainability and Performance in E-Learning & & & & & & & \multirow{2}{*}{1} & & & &
\end{tabular}

Further, '1's are put in the SSIM through the transitive relationship between two variables. The transitive relation exists between two variables $i$ and $j$ if there is a variable $k$, such that variable $i$ leads to $\mathrm{j}$ through $\mathrm{k}$ (i.e., $\mathrm{i} \rightarrow \mathrm{k}, \mathrm{k} \rightarrow \mathrm{j}$; then $\mathrm{i} \rightarrow \mathrm{k}$ ). The process was repeated for all the variables and the result is given in Table 5; transitivity is represented by asterisks with 1 , that is, $1^{*}$. Also, the driving power and dependence are given by adding all ' 1 's for each variable in Table 5. 
Table 5. Final reachability matrix.

\begin{tabular}{cccccccccccccccccc}
\hline $\begin{array}{c}\text { Sr. } \\
\text { No. }\end{array}$ & Elements & $\mathbf{1}$ & $\mathbf{2}$ & $\mathbf{3}$ & $\mathbf{4}$ & $\mathbf{5}$ & $\mathbf{6}$ & $\mathbf{7}$ & $\mathbf{8}$ & $\mathbf{9}$ & $\mathbf{1 0}$ & $\mathbf{1 1}$ & $\mathbf{1 2}$ & $\mathbf{1 3}$ & $\mathbf{1 4}$ & $\mathbf{1 5}$ & $\begin{array}{c}\text { Driving } \\
\text { Power }\end{array}$ \\
\hline 1. & Network Security & 1 & 0 & 0 & 1 & 0 & 1 & $1^{*}$ & 1 & 0 & 0 & 0 & $1^{*}$ & 0 & 1 & 1 & 8 \\
\hline 2. & Efficient Tech. Infrastructure & 1 & 1 & 0 & 1 & 1 & 1 & $1^{*}$ & 1 & 1 & 1 & 1 & $1^{*}$ & $1^{*}$ & 1 & 1 & 14 \\
\hline 3. & Organizational Infra. Readiness & 1 & 1 & 1 & 1 & 1 & 1 & 1 & 1 & 1 & 1 & 1 & 1 & 1 & 1 & 1 & 15 \\
\hline 4. & User-Friendly and Well-Organized & 0 & 0 & 0 & 1 & 0 & 1 & $1^{*}$ & 1 & 0 & 0 & 0 & 1 & 0 & 1 & 1 & 7 \\
\hline 5. & Appropriate. E-Learning Course Design & $1^{*}$ & 0 & 0 & 1 & 1 & 1 & 1 & 1 & 0 & 1 & 1 & 1 & 1 & 1 & 1 & 12 \\
\hline 6. & Stakeholders Training & 0 & 0 & 0 & 0 & 0 & 1 & $1^{*}$ & 0 & 0 & 0 & 0 & 0 & 0 & 0 & 1 & 3 \\
\hline 7. & Course Flexibility & 0 & 0 & 0 & 0 & 0 & 0 & 1 & 0 & 0 & 0 & 0 & 0 & 0 & 0 & 1 & 2 \\
\hline 8. & Understandable Relevant Content & 0 & 0 & 0 & 0 & 0 & 0 & 0 & 1 & 0 & 0 & 0 & 0 & 0 & 0 & 1 & 2 \\
\hline 9. & Commitment & 0 & 0 & 0 & 1 & 0 & 1 & $1^{*}$ & 1 & 1 & 0 & 0 & $1^{*}$ & 0 & 1 & 1 & 8 \\
\hline 10. & Computer Competency & $1^{*}$ & 0 & 0 & $1^{*}$ & 0 & 1 & $1^{*}$ & 1 & 0 & 1 & 0 & $1^{*}$ & 0 & 1 & 1 & 9 \\
\hline 11. & Interaction with Instructor & 0 & 0 & 0 & $1^{*}$ & 0 & 1 & 1 & 1 & 0 & 0 & 1 & 1 & 1 & 1 & 1 & 9 \\
\hline 12. & Interaction with other Students & 0 & 0 & 0 & 0 & 0 & 0 & 1 & 0 & 0 & 0 & 0 & 1 & 0 & 0 & 1 & 3 \\
\hline 13. & Motivation & 0 & 0 & 0 & 1 & 0 & 1 & $1^{*}$ & $1^{*}$ & 0 & 0 & 0 & 1 & 1 & 1 & 1 & 8 \\
\hline 14. & Easy Language Communication & 0 & 0 & 0 & 0 & 0 & 0 & 0 & 1 & 0 & 0 & 0 & 0 & 0 & 1 & 1 & 3 \\
\hline & Appropriate System for Enhancing & & & & & & & & & & & & & & & & \\
15. & Sustainability and Performance in & 0 & 0 & 0 & 0 & 0 & 0 & 0 & 0 & 0 & 0 & 0 & 0 & 0 & 0 & 1 & 1 \\
\hline & E-Learning & & & & & & & & & & & & & & & & \\
\hline
\end{tabular}

\subsection{Partitioning Process of the Reachability Matrix}

The partitioning process helps in identifying the hierarchy in the variables. With the help of the final reachability matrix, a reachability and antecedent set of variables for each variable was identified. The reachability set includes the variable itself and others that it helps to accomplish, whereas the antecedent set includes itself and other variables that help in accomplishing it. The intersection of these two reachability and antecedent sets was then calculated. The variable that had its reachability and intersection set equal became the top-level variable and was removed for the second iteration. The process was repeated until all the variables' levels were estimated. The resultant levels of all variables are shown in Table 6.

Table 6. Variables' levels through iteration I-IX.

\begin{tabular}{cccccc}
\hline Iteration & Elements (Mi) & $\begin{array}{c}\text { Reachability } \\
\text { R(Mi) Set }\end{array}$ & Antecedent Set A(Ni) & $\begin{array}{c}\text { Intersection Set, } \\
\text { R(Mi) } \cap \text { A(Ni) }\end{array}$ & Level \\
\hline I & 15 & 15 & $1,2,3,4,5,6,7,8,9,10,11,12,13,14,15$ & 15 & I \\
II & 7 & 7 & $1,2,3,4,5,6,7,9,10,11,12,13$ & 7 & II \\
II & 8 & 8 & $1,2,3,4,5,8,9,10,11,13,14$ & 8 & II \\
III & 6 & 6 & $1,2,3,4,5,6,9,10,11,13$ & 6 & III \\
III & 12 & 12 & $1,2,3,4,5,9,10,11,12,13$ & 12 & III \\
III & 14 & 14 & $1,2,3,4,5,9,10,11,13,14$ & 14 & III \\
IV & 4 & 4 & $1,2,3,4,5,9,10,11,13$ & 4 & IV \\
V & 1 & 1 & $1,2,3,5,10$ & 1 & V \\
V & 9 & 9 & $2,3,9$ & 9 & V \\
V & 13 & 13 & $2,3,5,11,13$ & 13 & V \\
VI & 10 & 10 & $2,3,5,10$ & 10 & VI \\
VI & 11 & 11 & $2,3,5,11$ & 11 & VI \\
VII & 5 & 5 & $2,3,5$ & 5 & VII \\
VIII & 2 & 2 & 2,3 & 2 & VIII \\
IX & 3 & 3 & 3 & 3 & IX \\
\hline
\end{tabular}

\subsection{Development of Conical Matrix, Diagraph, and Final ISM Model}

Once the partitioned reachability matrix was obtained, the next matrix known as the conical matrix could easily be derived from this matrix. Element 15 (Appropriate System for Enhancing Sustainability and Performance in E-Learning) was found at first level, that is, Level I, while elements 7 (Interaction with Instructor) and 8 (Interaction with other students) were found at the second level, that is, Level II, and elements 6 (Computer Competency) and 12 (Motivation) were obtained at third level, that is, 
Level III. Likewise, all other variables were checked and grouped together if they appeared to be on the same level. On rearranging the matrix, a conical matrix was obtained, which is shown in Table 7. The conical matrix was employed to frame the diagraphs and final model. The digraph is a directed graph that helps in visualizing the contextual relationship. Afterwards, by removing transitiveness and replacing node numbers with description, the final ISM model was derived as shown in Figure 1, and as discussed in the results section.

Table 7. Formation of conical matrix.

\begin{tabular}{|c|c|c|c|c|c|c|c|c|c|c|c|c|c|c|c|c|}
\hline Sr. No. & Elements & 15 & 7 & 8 & 6 & 12 & 14 & 4 & 1 & 9 & 13 & 10 & 11 & 5 & 2 & 3 \\
\hline 15 & $\begin{array}{c}\text { Appropriate System for Enhancing } \\
\text { Sustainability and Performance in E-Learning }\end{array}$ & 1 & 0 & 0 & 0 & 0 & 0 & 0 & 0 & 0 & 0 & 0 & 0 & 0 & 0 & 0 \\
\hline 7 & Interaction with Instructor & 1 & 1 & 0 & 0 & 0 & 0 & 0 & 0 & 0 & 0 & 0 & 0 & 0 & 0 & 0 \\
\hline 6 & Computer Competency & 1 & 1 & 0 & 1 & 0 & 0 & 0 & 0 & 0 & 0 & 0 & 0 & 0 & 0 & 0 \\
\hline 12 & Motivation & 1 & 1 & 0 & 0 & 1 & 0 & 0 & 0 & 0 & 0 & 0 & 0 & 0 & 0 & 0 \\
\hline 14 & Easy Language Communication & 1 & 0 & 1 & 0 & 0 & 1 & 0 & 0 & 0 & 0 & 0 & 0 & 0 & 0 & 0 \\
\hline 9 & Stakeholders Training & 1 & 1 & 1 & 1 & 1 & 1 & 1 & 0 & 1 & 0 & 0 & 0 & 0 & 0 & 0 \\
\hline 13 & Commitment & 1 & 1 & 1 & 1 & 1 & 1 & 1 & 0 & 0 & 1 & 0 & 0 & 0 & 0 & 0 \\
\hline 10 & Course Flexibility & 1 & 1 & 1 & 1 & 1 & 1 & 1 & 1 & 0 & 0 & 1 & 0 & 0 & 0 & 0 \\
\hline 11 & Understandable Relevant Content & 1 & 1 & 1 & 1 & 1 & 1 & 1 & 0 & 0 & 1 & 0 & 1 & 0 & 0 & 0 \\
\hline 5 & Appropriate. E-Learning Course Design & 1 & 1 & 1 & 1 & 1 & 1 & 1 & 1 & 0 & 1 & 1 & 1 & 1 & 0 & 0 \\
\hline 2 & Efficient Tech. Infrastructure & 1 & 1 & 1 & 1 & 1 & 1 & 1 & 1 & 1 & 1 & 1 & 1 & 1 & 1 & 0 \\
\hline
\end{tabular}

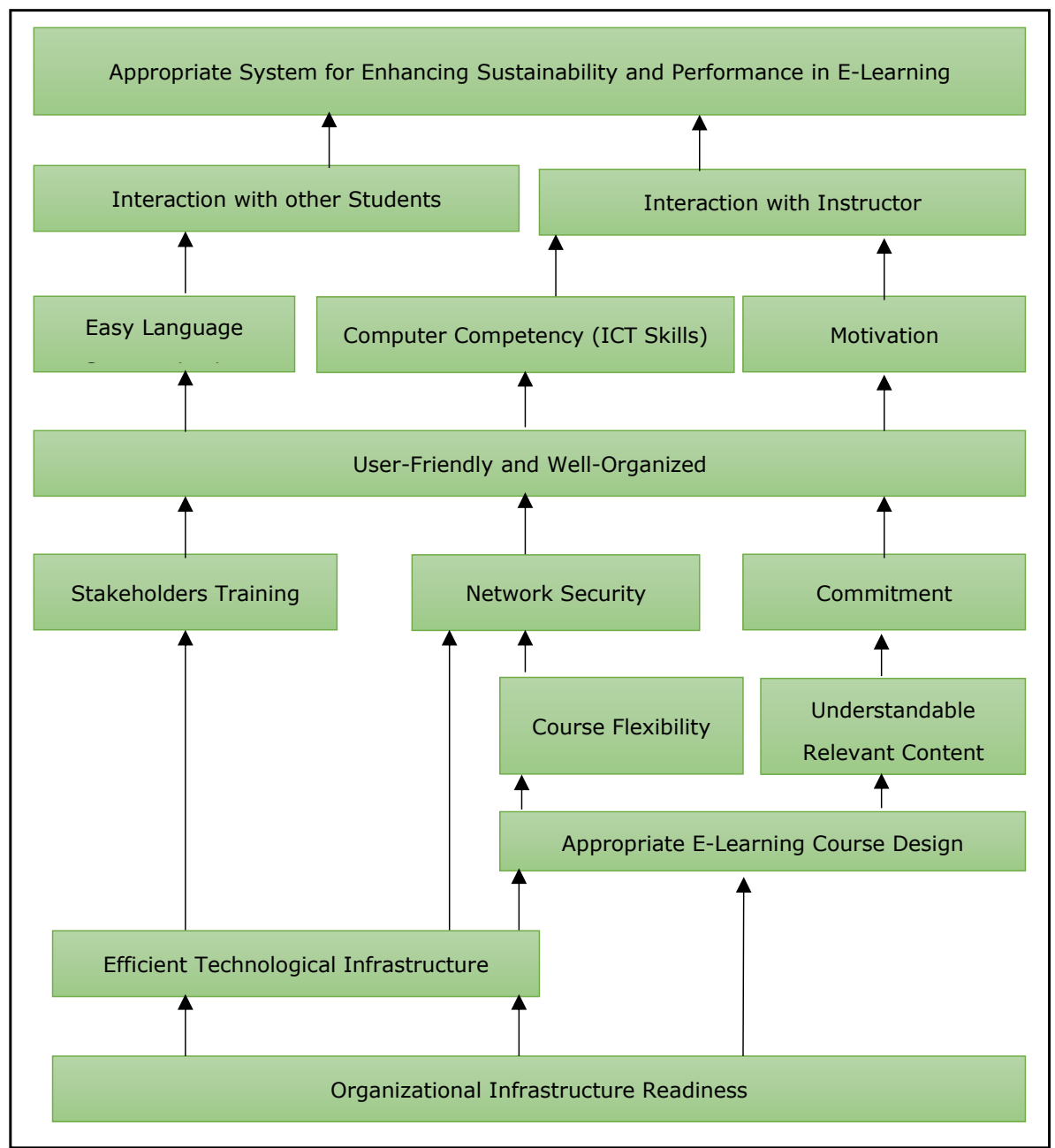

Figure 1. Interpretive structural modeling (ISM) based model for the appropriate system for enhancing sustainability and performance in E-Learning. 


\subsection{MICMAC Analysis}

The MICMAC analysis is based on the principle of multiplication properties of matrices. It provides the classification of the variable based on its driving power and driven power in terms of autonomous, dependent, linkage, and independent (driver) variables. The driving power and driven power of E-learning CSFs were derived from the final reachability matrix shown in Table 5. The MICMAC analysis diagram was prepared based on this data, as depicted in Figure 2. Variables with weak driving power and dependence are classified as autonomous, and juxtaposed to them are linkage variables with strong driving power and dependence. These two categories are devoid of any CSF, as shown in Figure 2. On the other hand, independent variables possess strong driving power and weak dependence and, contrary to them, are dependent variables. Thus, there are eight CSFs that fall under the quadrant IV (independent) and can be termed as enablers. Similarly, the seven CSFs of quadrant II (dependent) are more towards the desired outcome of E-learning.

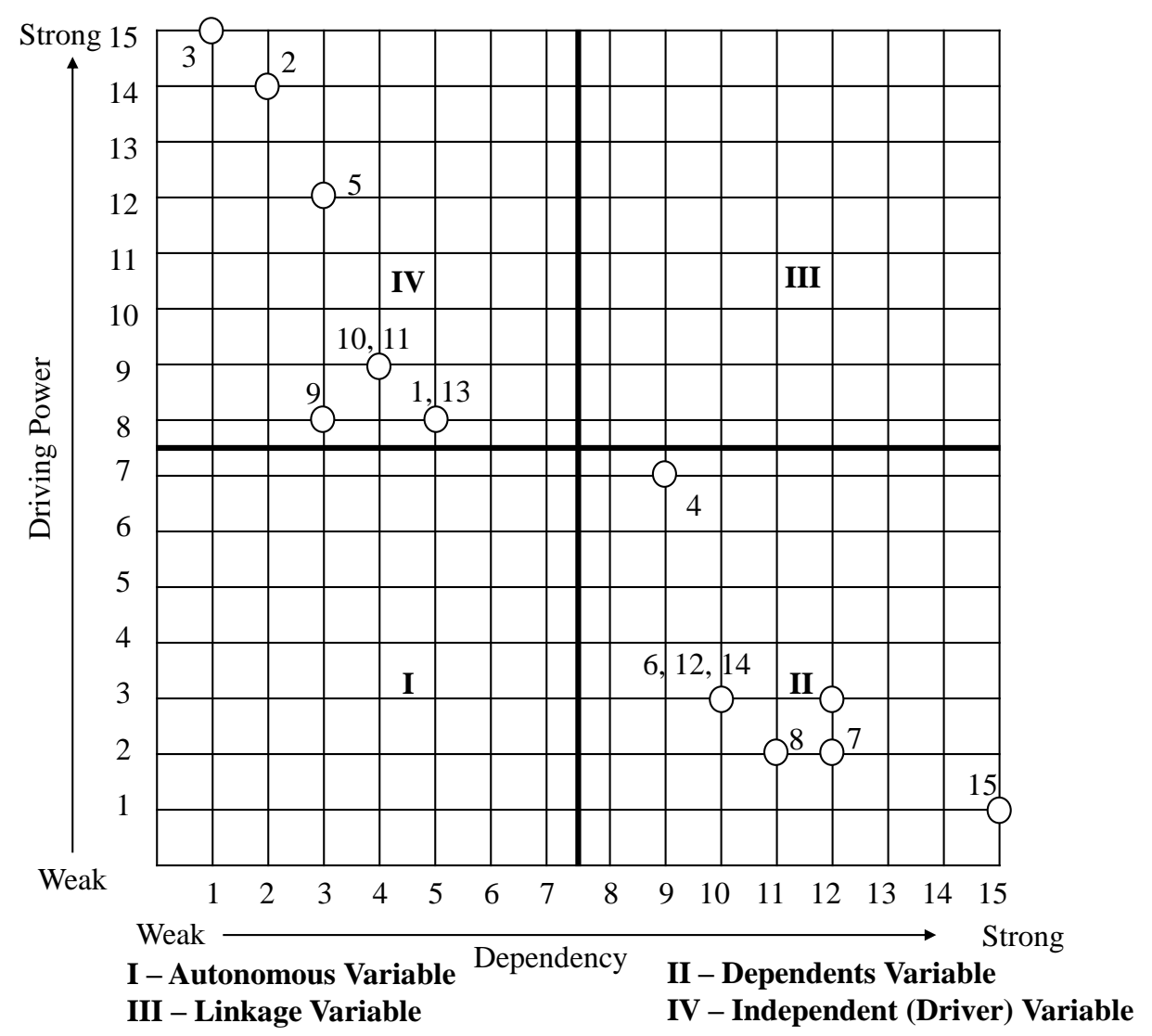

Figure 2. Driving power and dependence diagram.

\subsection{In-Depth Interviews to Validate the Model}

In total, six people with varying experiences with E-learning were contacted for the validation of the model, with the most experienced person being the Dean of E-learning, to the instructor with 12 years of experience. The model was shown and explained to them with the definitions of variables as needed. The in-depth interviews lasted between $15 \mathrm{~min}$ and an hour. The summarized, anonymous, and randomized interview transcripts are given below.

An interview with one of the reviewers lasted for one hour with important insights into his vision for the design of holistic approach for enabling E-learning. He stressed the importance of the needs of the people and design thinking approach. He proposed that the model should clearly depict four layers, starting from people, to IT, E-learning, and finally learning. By the people, he meant the organization with the budget, teams for setting up technology and E-learning resources, and students. He also 
put great emphasis upon the triangular interaction loop between students, instructional designer and instructors, and quality matters for the course design. He disagreed with the position of network security. He could see four layers into the proposed model, but was not able to comment on every variable of the model as it required more time and clarification. Moreover, he illustrated mostly on the independent variables of the model.

Another reviewer provided the most valuable input, which was that easy language communication, computer competency (ICT Skills), and motivation must help achieve both interaction with instructor and interaction with other students. Moreover, as per his remarks, network security is a misnomer and thus should be renamed as security and safety. Further, he stressed upon the need for financial and operational planning to be made an integral part in the earlier stages and in the designing, planning, and implementation of technology. One of the reviewers was in complete agreement with the model, except that easy language communication should not lead to simplification of content to the extent of leaving off abstract important concepts of a particular discipline.

The next reviewer proposed interchanging the motivation and commitment, as motivation will lead to commitment. Similarly, he suggested moving the user-friendly and well-organized factor above easy language communication, computer competency (ICT skills), and motivation, as the latter three will cause the former one. He also suggested some other names for network security, such as security and privileges, as well as to change student and instructor to learner and facilitator, respectively. He also felt it necessary to include culture somewhere, perhaps in easy language communication. Further, he emphasized upon the quality matters standards incorporation into the course design and checklist for organizational infrastructure readiness, in addition to defining policies, roles, and decision making.

Observation of one of the reviewers was that computer competence ICT skills should directly be followed by stakeholders' training. He also suggested interchanging the positions of motivation and commitment. Similarly, he said easy language communication should not be confused with the oversimplification of the course content. He also felt it necessary to rename or reposition network security. The sixth reviewer suggested broadening the scope of network security and said that it should prevent and monitor unauthorized access. He also recommended that stakeholders' training and commitment will also positively affect network security, in addition to the existing relationship between efficient technological infrastructure and course flexibility.

In summary, it can be concluded that the model comprehensively represents the major dimensions of the E-learning. Most reviewers are in agreement with the inter-relationships of the model variables. One major concern raised by almost all the reviewers is that network security is a misnomer. Therefore, it is suggested that it is renamed as security, access control, and privileges. Similarly, it seems reasonable to have the effects of easy language communication, computer competency (ICT skills), and motivation on both constructs such as interaction with other students and interaction with instructors, as pointed out by one of the reviewers. Interchanging the positions of commitment and motivation does not seem reasonable, as commitment is more on the dependent side and is expected to be exemplified by the organizers of E-learning, and that in turn will motivate the users of E-learning. As one of the studies suggests, intrinsic motivation of learners positively affects the learning outcome in gamified learning interventions [65], and attitude and motivation in general keeps the E-learning cause rolling $[9,66]$.

\section{Model Discussions}

In order to simplify the inter-relationship of fifteen E-learning constructs or critical success factors, the model will be explained in the following layers: E-learning resource accumulation, organization, and commitment; launch of E-learning; pre-learning dynamics; and learning.

Resource accumulation refers to the organizational infrastructure readiness and ensures that all the necessary resources are at the disposal. Resource organization entails well-tuned technological infrastructure followed by the appropriate E-learning course design using standard instructional 
design such as quality matters. Course design, if executed correctly, should demonstrate course flexibility and understandable relevant content.

Commitment to the resource side is essential among the organizing stakeholders. Moreover, it is reinforced by the appropriate training and inculcation of well-defined security, access control, and privileges. Once the resources are accumulated, organized, and committed in a systematic and optimal fashion, the user-friendly and well-organized E-learning is ready to be launched. Hereafter, the model may be seen to be transitioning into the dependent side and ultimately leading to the appropriate system for enhancing sustainability and performance in E-learning. In the E-learning environment, certain preconditions need to be met in order for learning to take place. These are easy language communication, computer competency (ICT skills), and motivation. These factors will lead to the interaction with other students and interaction with the instructor, and hence to productive learning.

\section{Conclusions, Limitations, and Future Work}

In the present digital era, it is of utmost importance to provide a learning environment free from constraints such as time, place, and learning mode. E-learning provides an answer to such constraints. However, it is important to ensure that sustainability and performance enhancement in E-learning implementation are accomplished along with delivery for global adoption of E-learning. The present research provides quantification, prioritization, and classification of CSFs of E-learning using ISM and MICMAC. The ISM model developed will help the university authority or management to understand the inter-relationships among E-learning CSFs for policy formulation, strategic decision making, and resource planning and optimization.

Management can attain the desired sustainability and performance of E-learning by carefully governing the independent CSFs such as organizational infrastructure readiness; efficient technology infrastructure; appropriate E-learning course design; course flexibility; understandable relevant content; stakeholders' training; security, access control, and privileges; commitment; and being user-friendly and well-organized. The strong presence of these independent CSFs will help in boosting the dependent CSFs including easy language communication, computer competency, and motivation, which are essential E-learning prerequisites. That ultimately will lead to the dynamics of learning in terms of improved interaction with instructor and interaction with other students. Gamification technology may also be synergized in E-learning for better learning motivation. Gamification technology helps in achieving a conducive environment for learning by enhancing teamwork with fun.

ISM utilizes the group decision-making technique to identify the contextual relationship between variables; therefore, it is not free from individual bias. However, efforts have been made to validate the model through six expert reviewers. The model has been found to represent important dimensions of E-learning and inter-relationships. Two important suggestions have been incorporated in the model discussion section, including renaming of network security to security, access control, and privileges and contribution of easy language communication, computer competency, and motivation to both interaction with instructor and interaction with other students. Further, a survey-based study can be conducted and structural equation modeling (SEM) can be applied to validate the model.

Author Contributions: Conceptualization, N.A., N.N.Q., and M.R.N.Q.; Formal analysis, M.R.N.Q.; Project administration, M.M.A.; Supervision, M.M.A.; Validation, N.A.; Writing—original draft, N.N.Q.; Writing一review \& editing, N.A.

Funding: This research was funded by Deanship of Scientific Research, King Khalid University, Kingdom of Saudi Arabia and the grant number is G. R. P.-35-39.

Acknowledgments: We would like to express our gratitude to Deanship of Scientific Research, King Khalid University, Kingdom of Saudi Arabia for funding this work, as well as family, friends, and colleagues for their constant inspiration and encouragement.

Conflicts of Interest: The authors declare no conflict of interest. 


\section{References}

1. Ahmad, N. Cloud computing: Technology, security issues and solutions. In Proceedings of the 2017 2nd International Conference on Anti-Cyber Crimes (ICACC), Abha, Saudi Arabia, 26-27 March 2017; pp. 30-35.

2. Irfan, M.; Ahmad, N. Internet of medical things: Architectural model, motivational factors and impediments. In Proceedings of the 2018 15th Learning and Technology Conference (L\&T), Jeddah, Saudi Arabia, 25-26 February 2018; pp. 6-13.

3. Yanuschik, O.V.; Pakhomova, E.G.; Batbold, K. E-learning as a way to improve the quality of educational for international students. Procedia-Soc. Behav. Sci. 2015, 215, 147-155. [CrossRef]

4. Villar, L.M.; Alegre, O.M. Measuring faculty learning in curriculum and teaching competence online courses. Interact. Learn. Environ. 2008, 16, 169-181. [CrossRef]

5. Liu, C.-H.; Chiang, T.-C.; Huang, Y.-M. Assessment of Effectiveness of Web-based Training on Demand. Interact. Learn. Environ. 2007, 15, 217-235. [CrossRef]

6. Wang, T.-H. Developing Web-based assessment strategies for facilitating junior high school students to perform self-regulated learning in an e-Learning environment. Comput. Educ. 2011, 57, 1801-1812. [CrossRef]

7. Brooks, S.; Roberts, E. 'Simultaneous immersion': How online postgraduate study contributes to the development of reflective practice among public service practitioners. Interact. Learn. Environ. 2016, 24, 1692-1705. [CrossRef]

8. Walker, R.; Voce, J.; Jenkins, M. Charting the development of technology-enhanced learning developments across the UK higher education sector: A longitudinal perspective (2001-2012). Interact. Learn. Environ. 2016, 24, 438-455. [CrossRef]

9. Papadakis, S.; Kalogiannakis, M. Using Gamification for Supporting an Introductory Programming Course. The Case of ClassCraft in a Secondary Education Classroom. In Interactivity, Game Creation, Design, Learning, and Innovation; Springer: Berlin Germany, 2017; pp. 366-375.

10. Navimipour, J.N.; Zareie, B. A model for assessing the impact of e-learning systems on employees' satisfaction. Comput. Human Behav. 2015, 53, 475-485. [CrossRef]

11. Shafaei, A.; Nejati, M.; Quazi, A.; von der Heidt, T. When in Rome, do as the Romans do. Do international students acculturation attitudes impact their ethical academic conduct? High. Educ. 2016, 71, 651-666. [CrossRef]

12. Yew, O.F.; Jambulingam, M. Critical Success Factors of E-learning Implementation at Educational Institutions. J. Interdiscip. Res. Educ. 2015, 5, 17-24.

13. Ordóñez, A.C. Predicting International Critical Success Factors in E-Learning: A Comparison of Four Universities from China, Mexico, Spain and USA. Ph.D. Thesis, Universitat Oberta de Catalunya, Barcelona, Spain, 2014.

14. Sangrà, A.; Vlachopoulos, D.; Cabrera, N. Building an inclusive definition of e-learning: An approach to the conceptual framework. Int. Rev. Res. Open Distrib. Learn. 2012, 13, 145-159. [CrossRef]

15. Robertson, I. Sustainable e-learning, activity theory and professional development. In Proceedings of the Ascilite 2008, Melbourne, Australia, 30 November-3 December 2008; pp. 819-826.

16. Chipere, N. A framework for developing sustainable e-learning programmes. Open Learn. J. Open Distance e-Learn. 2017, 32, 36-55. [CrossRef]

17. Stepanyan, K.; Littlejohn, A.; Margaryan, A. Sustainable e-learning: Toward a coherent body of knowledge. J. Educ. Technol. Soc. 2013, 16, 91-102.

18. Jenkins, M.; Browne, T.; Walker, R.; Hewitt, R. The development of technology enhanced learning: Findings from a 2008 survey of UK higher education institutions. Interact. Learn. Environ. 2011, 19, 447-465. [CrossRef]

19. Frimpon, M.F. A re-structuring of the critical success factors for e-learning deployment. Am. Int. J. Contemp. Res. 2012, 2, 115-127.

20. Ahmad, N.; Haleem, A.; Syed, A.A. Compilation of Critical Success Factors in Implementation of Enterprise Systems: A Study on Indian Organisations. Glob. J. Flex. Syst. Manag. 2013, 13, 217-232. [CrossRef]

21. Quadri, N.N.; Muhammad, A.; Sanober, S.; Rafik, M.; Shah, A. A Mixed Method Study for Investigating Critical Success Factors (CSFs) of E-Learning in Saudi Arabian Universities. Int. J. Adv. Comput. Sci. Appl. 2017, 8, 171-178.

22. Sage, A.P. Methodology for Large-Scale Systems; McGraw-Hill College: New York, NY, USA, 1977.

23. Kim, D.; Kim, Y.; Lee, N. A Study on the Interrelations of Decision-Making Factors of Information System (IS) Upgrades for Sustainable Business Using Interpretive Structural Modeling and MICMAC Analysis. Sustainability 2018, 10, 872. [CrossRef] 
24. Liu, Z.; Jiang, W.; Wu, Y.; Peng, Y. Risk Factors of Building Apartments for University Talent through the Agent Construction Mode in China: Interrelationship and Prioritization. Sustainability 2016, 8, 325. [CrossRef]

25. Rockart, J.F. Chief executives define their own data needs. Harv. Bus. Rev. 1979, 57, 81-93.

26. Mehregan, M.R.; Jamporazmey, M.; Hosseinzadeh, M.; Mehrafrouz, M. Proposing an approach for evaluating e-learning by integrating critical success factor and fuzzy AHP. In Proceedings of the 2011 International Conference on Innovation, Management and Service, Singapore, 16-18 September 2011; pp. 125-130.

27. Parsazadeh, N.; Zainuddin, N.M.M.; Ali, R.; Hematian, A. A review on the success factors of e-learning. In Proceedings of the International Conference on e-Technologies and Networks for Development (ICeND2013), Kuala Lumpur, Malaysia, 4-6 March 2013; pp. 42-49.

28. Raspopovic, M.; Jankulovic, A.; Runic, J.; Lucic, V. Success factors for e-learning in a developing country: A case study of Serbia. Int. Rev. Res. Open Distrib. Learn. 2014, 15, 1-23. [CrossRef]

29. Selim, H.M. Critical success factors for e-learning acceptance: Confirmatory factor models. Comput. Educ. 2007, 49, 396-413. [CrossRef]

30. Sun, P.-C.; Tsai, R.J.; Finger, G.; Chen, Y.-Y.; Yeh, D. What drives a successful e-Learning? An empirical investigation of the critical factors influencing learner satisfaction. Comput. Educ. 2008, 50, 1183-1202. [CrossRef]

31. Lin, C.-C.; Ma, Z.; Lin, R.C.-P. Re-examining the Critical Success Factors of e-learning from the EU perspective. Int. J. Manag. Educ. 2011, 5, 44-62. [CrossRef]

32. Sigama, K.; Kalema, B.M.; Kekwaletswe, R.M. Utilizing Web 2.0 and Free Open Source Software to advance e-learning in developing countries. In Proceedings of the e-Leadership Conference on Sustainable e-Government and e-Business Innovations (E-LEADERSHIP), Pretoria, South Africa, 4-5 October 2012; pp. 1-7.

33. Goi, C.L.; Ng, P.Y. E-learning in Malaysia: Success factors in implementing e-learning program. Int. J. Teach. Learn. High. Educ. 2009, 20, 237-246.

34. Wibowo, Y.F.A.; Laksitowening, K.A. Redefining e-learning readiness model. In Proceedings of the International Conference on Information and Communication Technology (ICoICT), Bali, Indonesia, 27-29 May 2015; pp. 552-557.

35. FitzPatrick, T. Key Success Factors of eLearning in Education: A Professional Development Model to Evaluate and Support eLearning. US-China Educ. Rev. A 2012, 9, 789-795.

36. Premchaiswadi, W.; Porouhan, P.; Premchaiswadi, N. An empirical study of the key success factors to adopt e-learning in Thailand. In Proceedings of the International Conference on Information Society (i-Society 2012), London, UK, 25-28 June 2012; pp. 333-338.

37. Alamin, H.A.A.; Elgabar, E.E.A. Success Factors for Adopting E-learning Application in Sudan. Int. J. Soft Comput. Eng. 2014, 3, 128-131.

38. Ansong, E.; Boateng, S.L.; Boateng, R.; Effah, J. Determinants of E-Learning Adoption in Universities: Evidence from a Developing Country. In Proceeding of Annual Hawaii International Conference on System Sciences, Koloa, HI, USA, 5-8 January 2016; pp. 21-30.

39. Stacey, E.; Gerbic, P. Success factors for blended learning. In Proceedings of the Ascilite 2008: Hello! Where are you in the landscape of educational technology? Melbourne, Australia, 30 November-3 December 2008; pp. 964-968.

40. Ozkan, S.; Koseler, R. Multi-dimensional students' evaluation of e-learning systems in the higher education context: An empirical investigation. Comput. Educ. 2009, 53, 1285-1296. [CrossRef]

41. Menchaca, M.P.; Bekele, T.A. Learner and instructor identified success factors in distance education. Distance Educ. 2008, 29, 231-252. [CrossRef]

42. Mosakhani, M.; Jamporazmey, M. Introduce critical success factors (CSFs) of elearning for evaluating e-learning implementation success. In Proceedings of the International Conference on Educational and Information Technology (ICEIT), Chongqing, China, 17-19 September 2010.

43. Musa, M.A.; Othman, M.S. Critical success factor in e-Learning: An examination of technology and student factors. Int. J. Adv. Eng. Technol. 2012, 3, 140.

44. Keramati, A.; Afshari-Mofrad, M.; Kamrani, A. The role of readiness factors in E-learning outcomes: An empirical study. Comput. Educ. 2011, 57, 1919-1929. [CrossRef] 
45. Laily, N.; Kurniawati, A.; Puspita, I.A. Critical success factor for e-learning implementation in Institut Teknologi Telkom Bandung using Structural Equation Modeling. In Proceedings of the International Conference of Information and Communication Technology (ICoICT), Bandung, Indonesia, 20-22 March 2013; pp. 427-432.

46. Bahramnezhad, F.; Asgari, P.; Ghiyasvandian, S.; Shiri, M.; Bahramnezhad, F. The Learners' Satisfaction of E-learning: A Review Article. Am. J. Educ. Res. 2016, 4, 347-352.

47. Khan, B.H. E-Learning Quick Checklist; IGI Global: Hershey, PA, USA, 2005.

48. Fresen, J.W. Factors influencing lecturer uptake of e-learning. Teach. English Technol. 2011, 11, 81-97.

49. Anthony, M.; Sue, H. Critical success in e-learning: The human factor. Ashridge J. 2006, Spring, 32-39.

50. Lee-Post, A. e-Learning Success Model: An Information Systems Perspective. Electron. J. e-Learn. 2009, 7, 61-70.

51. Arora, R.; Chhabra, I. Extracting components and factors for quality evaluation of e-learning applications. In Proceedings of the 2014 Recent Advances in Engineering and Computational Sciences (RAECS), Chandigarh, India, 6-8 March 2014; pp. 1-5.

52. Bhuasiri, W.; Xaymoungkhoun, O.; Zo, H.; Rho, J.J.; Ciganek, A.P. Critical success factors for e-learning in developing countries: A comparative analysis between ICT experts and faculty. Comput. Educ. 2012, 58, 843-855. [CrossRef]

53. Cheawjindakarn, B.; Suwannatthachote, P.; Theeraroungchaisri, A. Critical success factors for online distance learning in higher education: A review of the literature. Creat. Educ. 2012, 3, 61-66. [CrossRef]

54. Odunaike, S.A.; Olugbara, O.O.; Ojo, S.O. E-learning Implementation Critical Success Factors. In Proceedings of the International Multi Conference of Engineers and Computer Scientists, Hong Kong, China, 13-15 March 2013; pp. 560-565.

55. Puri, G. Critical success Factors in e-Learning-An empirical study. Int. J. Multidiscip. Res. 2012, 2, $149-161$.

56. Gannon-Leary, P.; Fontainha, E. Communities of Practice and Virtual Learning Communities: Benefits, Barriers and Success Factors. eLearning Papers. 2007. Available online: https:/ / papers.ssrn.com/sol3/papers. cfm?abstract_id=1018066 (accessed on 1 January 2017).

57. Andersson, A. Seven major challenges for e-learning in developing countries: Case study eBIT, Sri Lanka. Int. J. Educ. Dev. Using ICT 2008, 4, 45-62.

58. Salmerón-Manzano, E.; Manzano-Agugliaro, F. The Higher Education Sustainability through Virtual Laboratories: The Spanish University as Case of Study. Sustainability 2018, 10, 4040. [CrossRef]

59. Martínez-Cerdá, J.F.; Torrent-Sellens, J.; González-González, I.; Ficapal-Cusí, P. Opening the Black-Box in Lifelong E-Learning for Employability: A Framework for a Socio-Technical E-Learning Employability System of Measurement (STELEM). Sustainability 2018, 10, 1014. [CrossRef]

60. Barth, M.; Burandt, S. Adding the "e-" to learning for sustainable development: Challenges and innovation. Sustainability 2013, 5, 2609-2622. [CrossRef]

61. AbuSneineh, W.; Zairi, M. An evaluation framework for E-learning effectiveness in the Arab World. Int. Encycl. Educ. 2010, 521-535. [CrossRef]

62. Chapnick, S. Are You Ready for e-Learning. Retrieved on Jan 2017. 2000. Available online: http:/ / blog.uny.ac. id/nurhadi/files/2010/08/are_you_ready_for_elearning.pdf (accessed on 10 September 2018).

63. Katuk, N.; Kim, J.; Ryu, H. Experience beyond knowledge: Pragmatic e-learning systems design with learning experience. Comput. Hum. Behav. 2013, 29, 747-758. [CrossRef]

64. Kim, J.; Lee, W. Assistance and possibilities: Analysis of learning-related factors affecting the online learning satisfaction of underprivileged students. Comput. Educ. 2011, 57, 2395-2405. [CrossRef]

65. Buckley, P.; Doyle, E. Gamification and student motivation. Interact. Learn. Environ. 2016, 24, 1162-1175. [CrossRef]

66. Rodríguez-Ardura, I.; Meseguer-Artola, A. What leads people to keep on e-learning? An empirical analysis of users'experiences and their effects on continuance intention. Interact. Learn. Environ. 2016, 24, 1030-1053. [CrossRef]

(C) 2018 by the authors. Licensee MDPI, Basel, Switzerland. This article is an open access article distributed under the terms and conditions of the Creative Commons Attribution (CC BY) license (http:/ / creativecommons.org/licenses/by/4.0/). 